\title{
DYSPHASIA FOLLOWING RIGHT TEMPORAL LOBECTOMY IN A RIGHT-HANDED MAN
}

\author{
BY \\ G. ETTLINGER, C. V. JACKSON, and O. L. ZANGWILL \\ From the Psychological Department, National Hospital, Queen Square, London
}

It is well known that excisions of parts of the right hemisphere very seldom occasion dysphasia. In a survey of Penfield's cases of cortical excision for the relief of focal epilepsy, Roberts (1951) reports that aphasia followed operations on the right hemisphere only twice in 258 right-handed patients and three times in 23 left-handed patients. Unfortunately, no data as to the loci of the excisions or of the types of dysphasia are given. In the present paper a case is reported in which marked and relatively persistent dysphasia followed right temporal lobectomy. This case is of exceptional interest in so far as the patient was ostensibly right-kanded. It thus represents a further addition to the sparse literature of "crossed aphasia" (Bramwell, 1899) in dextrals.

\section{Case Report}

Case No. 47010.-A labourer, aged 35, was admitted with a history of temporal lobe seizures of 16 years' duration. He first developed attacks in 1937, shortly after an illness consisting of acute right otitis media, acute right mastoiditis, and signs and symptoms of a cerebral abscess, which led to a negative exploration of the right sphenoido-temporal lobe. Early in 1949 the right mastoid was re-explored and later in the same year a radical mastoidectomy performed. Since this last operation the patient's attacks had become rather more frequent and on some occasions involved loss of consciousness. On neurological examination, there were no abnormal physical signs and an air-encephalogram was negative. The E.E.G. findings were reported as compatible with scarring from past inflammation involving the anterior portion of the inferior surface of the right temporal lobe. In view of the normal air-encephalogram, the patient was discharged on anti-convulsant medication.

He was readmitted nine months later on account of persistent generalized epileptic attacks, impairment of recent memory, and deterioration in personality. $\mathrm{He}$ had become slovenly in his dress, dirty in his habits, and liable to violent outbursts of temper. There were some paranoid features. A "metrazol"E.E.G. showed a single consistent focus in the right anterior temporal region. On July 1, 1944, formal right temporal lobectomy was performed (Mr. Wylie McKissock). After operation, the patient was at first totally aphasic, but would make some attempt to answer questions in writing (only single words could be produced). Speech returned fairly rapidly over the next few days but considerable dysphasia, predominantly receptive, remained in evidence during the ensuing weeks. Unfortunately, the patient's psychiatric state underwent no significant improvement and he was discharged elsewhere five weeks after operation.

Psychological Examinations.-On examination nine months before operation the patient attained an I.Q. of 95 on the Wechsler-Bellevue full scale. Although no dysphasia was apparent in conversation, occasional difficulty in finding words was noticed during testing and there were signs of minimal verbal defect on language intelligence tests. On the other hand, reading, writing, and calculation were not impaired. Re-examination two weeks before operation revealed no significant change in intellectual or linguistic attainment.

On examination two weeks post-operatively the patient's speech was markedly dysphasic. Although individual words were articulated normally, speech as a whole was marked by grave expressive defects. These comprised limited and inadequate formulation ("verbal aphasia "), condensed expression ("telegram-style "), and alteration in the prosodic quality of speech ("dysprosody" of Monrad-Krohn, 1947). The patient's speech was staccato and somewhat explosive, with marked disorder of modulation and " speech melody".

But little or no paraphasia appeared in spoken speech and naming objects was in general good. The patient could write his name and address without hesitation and readily copy a printed text. But writing either spontaneously or to dictation was much impaired, with omission of letters and frequent substitutions among the "small" parts of speech. For example : "To be or not to be. That is the question" was written as "Or not be not that as a qestion ". On the receptive side the patient showed a marked defect in comprehension. Although ordinary conversation appeared to be fairly well understood, simple requests, e.g., selecting an object to oral command, were seldom carried out correctly and the patient's responses showed marked perseveration of the type described by Pick and Thiele (1931) in temporal lobe aphasia. Complicated requests were never understood. The patient was unable to understand the request to repeat words after the examiner and his immediate verbal memory could not 
therefore be tested. He was, however, able to read aloud without gross error and to explain newspaper headlines more or less correctly. His interpretation of pictures, on the other hand, was excessively poor.

On re-examination three weeks post-operatively, speech showed some further improvement and the patient could now express his ideas at a simple level and conduct a conversation. His utterance, however, remained staccato and lacking in proper rhythm and stress. Comprehension, too, had very slightly improved and the patient was now able to repeat digits and short phrases to oral request. On the other hand, he still made many mistakes in carrying out instructions, even when these were quite simple and straightforward. Recognition of objects by sound (keys, matches) was intact. The patient could count coins scattered on the table and give the correct total in shillings and pence ; he could not, however, do the simplest calculation in his head. In writing, literal mistakes were still present but phrases could now be taken down to dictation without gross error. Reading aloud was adequate but the patient's grasp of the sense of what he read appeared somewhat defective. Drawing of objects from memory was excessively poor. On formal tests, the patient showed no deterioration on Kohs' block designs compared with the pre-operative level but performed very poorly on the picture-arrangement sub-test of the WechslerBellevue scale. His performance in the Weigl sorting test was concrete, perseverative, and obviously much impaired.

The patient was re-examined 19 weeks postoperatively (by kind permission of the Physician Superintendent, Springfield Hospital). His oral speech was now found to be fluent but an occasional paraphasic error was recorded. Modulation and "speech melody" had also improved and no mistakes were made on object-naming tests. On the other hand, comprehension of speech remained markedly defective. Thus, when asked to undo the second button of his jacket, the patient undid all his buttons and then proceeded to do them up again. Very simple mental arithmetic could now be undertaken but the patient was unable to follow the simplest arithmetical reasoning test, whether given orally or in writing. Reading aloud was somewhat jerky and there were occasional paraphasic slips, but the patient appeared to grasp the sense of what he read. Writing to dictation still produced an occasional literal error. On intellectual testing, the patient's performance remained at much the same level as before : performance on the Weigl test was still impaired and his explanations of proverbs remained grossly defective. The patient was garrulous, discursive, and totally without insight ; his psychiatric condition remained unimproved.

Handedness in this case was of exceptional interest. The patient had always regarded himself as right-handed and was observed to favour his right hand in all ordinary unimanual activities. He denied strongly that he had been left-handed as a child or had ever wanted to write with the left hand. At the same time, he claimed considerable facility in the use of either hand and stated that he could use a hammer or saw, or throw a ball, left-handed. Attempts to write with the left hand, however, produced results no better than those commonly obtained from fully right-handed individuals. The patient appeared to have no definite foot-preference. His eye-dominance could not be satisfactorily tested on account of dysphasia.

Inquiry revealed that both parents had been righthanded. Of his seven siblings, one sister was left-handed (apart from writing), left-footed but right eye-dominant. Her husband and five children were, however, righthanded. The remaining six siblings were fully righthanded, as were also the patient's wife and their five children.

\section{Discussion}

The unusual feature in this case is the incidence of a severe post-operative dysphasia in an ostensibly right-handed man. Although expressive speech recovered rapidly and almost completely, the severe and persistent receptive disability ("word-deafness") strongly suggests that the major hemisphere-or at any rate the major temporal lobe-was on the right side. This inference is supported by the fact that the patient was himself partly ambidextrous and that one of his sisters was fully left-handed. There is thus good evidence of definite-if relatively weak-sinistral characteristics, both familial and personal. Indeed the possibility that the patient was himself a " shifted sinistral", i.e., a congenitally left-handed man converted by early training to the use of the right hand, cannot be wholly excluded, though no evidence to this effect was forthcoming. In our view, it is more plausible to suppose that the patient showed weak inborn specialization of hand-preference, i.e., that his ambilaterality was constitutional rather than acquired by training. If this view be correct, the patient is to be classified not as a "shifted sinistral" but as a congenitally, if weakly, right-handed man.

This interpretation gains a measure of support from certain cases of broadly similar type previously reported in the literature. Excluding certain very early case reports, we have been able to trace references to 15 cases in which aphasia has been found in association with right-sided lesions in right-handed patients. The main features presented by these cases are summarized in the Table. It will be seen that some degree of ambidexterity was present in three of the cases and a familial sinistral tendency in nine. Indeed there are only two really well authenticated cases (Mendel, 1914 ; Marinesco, Grigoresco, and Axente, 1938) in which neither personal nor familial indications of left-handedness could be established. It would therefore seem justifiable to anticipate some sinistral tendency in a case such as ours. At the same time it is important to bear in mind that not every case of aphasia in 
TABLE

ANALYSIS OF 15 CASES FROM THE LITERATURE

\begin{tabular}{|c|c|c|c|c|c|c|}
\hline \multirow{2}{*}{ Case } & \multicolumn{2}{|c|}{ Handed ness } & \multirow{2}{*}{ Lesion } & \multirow{2}{*}{ Verification } & \multirow{2}{*}{ Physical Signs } & \multirow{2}{*}{ Speech Disorder } \\
\hline & Personal & Familial & & & & \\
\hline Souques (1910) & Right & Not stated & R. vascular & - & Left hemiplegia & Mixed aphasia : severe, \\
\hline $\begin{array}{l}\text { Mendel (1914) } \\
\text { Kennedy (1916, } \\
\text { Case 4) }\end{array}$ & $\begin{array}{l}\text { Right } \\
\text { Right }\end{array}$ & $\begin{array}{l}\text { Right } \\
\text { Both parents left }\end{array}$ & $\begin{array}{l}\text { R. embolism } \\
\text { R. Rolandic gumma }\end{array}$ & $\begin{array}{l}\text { Necropsy } \\
-\end{array}$ & $\begin{array}{l}\text { Left hemiparesis } \\
\text { Left-sided focal seiz- } \\
\text { ures, post-ictal } \\
\text { left hemiplegia }\end{array}$ & $\begin{array}{l}\text { Motor aphasia : persistent } \\
\text { Post-ictal aphasia after } \\
\text { each attack }\end{array}$ \\
\hline $\begin{array}{l}\text { Kennedy (1916, } \\
\text { Case 5) }\end{array}$ & Right & Two brothers left & R. subcortical glioma & Operation & Mild left hemiplegia & $\begin{array}{l}\text { Post-operative aphasia : } \\
\text { duration } 10 \text { days }\end{array}$ \\
\hline $\begin{array}{l}\text { Kennedy (1916, } \\
\text { Case 6) }\end{array}$ & Right & $\begin{array}{l}\text { Mother, brother, } \\
\text { daughter left }\end{array}$ & R. cerebral haemorrhage & - & Left hemiplegia & Mixed aphasia: severe \\
\hline $\begin{array}{l}\text { Claude and } \\
\text { Schaeffer (1921) }\end{array}$ & Right & Right & R. cerebral haemorrhage & 一 & $\begin{array}{l}\text { Left-hemiparesis ; } \\
\text { left-sided sensory } \\
\text { loss }\end{array}$ & $\begin{array}{l}\text { Motor aphasia : rapid but } \\
\text { incomplete restitution ; } \\
\text { dysgraphia, dyscalculia }\end{array}$ \\
\hline $\begin{array}{l}\text { Rothschild } \\
\text { (1931, Case 1) }\end{array}$ & Right & $\begin{array}{l}\text { Parents right; } 2 \text { (of } \\
\text { 8) siblings left }\end{array}$ & R. embolism & - & $?$ & $\begin{array}{l}\text { Receptive dysphasia : } \\
\text { transient }\end{array}$ \\
\hline Rothschild & Right & One son left & R. cerebral haemorrhage & - & $?$ & Motor aphasia \\
\hline Stone (1934) . & Right & $\begin{array}{c}\text { Parents believed } \\
\text { right }\end{array}$ & R. temporal tumour & Necropsy & $\begin{array}{l}\text { Left quadrantic field } \\
\text { defect }\end{array}$ & $\begin{array}{l}\text { Receptive dysphasia, dys- } \\
\text { lexia, dysgraphia, dys- } \\
\text { calculia }\end{array}$ \\
\hline $\begin{array}{l}\text { Weisenburg and } \\
\text { McBride (1935, } \\
\text { Case 10) }\end{array}$ & $\begin{array}{l}\text { Right, partly } \\
\text { ambidextrous }\end{array}$ & $\begin{array}{l}\text { Some left-handed- } \\
\text { ness in family; one } \\
\text { child left-handed }\end{array}$ & $\begin{array}{l}\text { R. middle cerebral } \\
\text { thrombosis }\end{array}$ & - & $\begin{array}{l}\text { Left hemiplegia; left- } \\
\text { sided sensory loss }\end{array}$ & $\begin{array}{l}\text { Expressive dysphasia : } \\
\text { severe, persistent }\end{array}$ \\
\hline $\begin{array}{l}\text { Weisenburg and } \\
\text { McBride (1935, } \\
\text { Case 26) }\end{array}$ & Right & Not stated & $\begin{array}{l}\text { R. middle cerebral } \\
\text { thrombosis }\end{array}$ & 一 & $\begin{array}{l}\text { Left hemiplegia: left- } \\
\text { sided sensory loss }\end{array}$ & $\begin{array}{l}\text { Expressive dysphasia : } \\
\text { moderate, persistent }\end{array}$ \\
\hline $\begin{array}{l}\text { Chesher (1936, } \\
\text { Case 9) }\end{array}$ & $\begin{array}{c}\text { Right, } \\
\text { virtually }\end{array}$ & $\begin{array}{l}\text { One sister, } \\
\text { one son left }\end{array}$ & R. cerebral tumour & Operation & $?$ & Aphasia \\
\hline $\begin{array}{l}\text { Marinesco and } \\
\text { others (1938) }\end{array}$ & $\begin{array}{l}\text { ambidextrous } \\
\text { Right }\end{array}$ & Right & R. vascular & Necropsy & Left hemiplegia & $\begin{array}{l}\text { Mixed dysphasia : per- } \\
\text { sistent }\end{array}$ \\
\hline $\begin{array}{l}\text { Subirana (1952, } \\
\text { Case 9) }\end{array}$ & Right & $\begin{array}{l}\text { One brother, } \\
\text { one son left }\end{array}$ & R. vascular & $\begin{array}{l}\text { R. temporal } \\
\text { E.E.G.focus }\end{array}$ & Left hemiplegia & Dysphasia : transient \\
\hline $\begin{array}{c}\text { Whitty (1954, } \\
\text { unpublished) }\end{array}$ & $\begin{array}{c}\text { Right, } \\
\text { partially } \\
\text { ambidextrous }\end{array}$ & $\begin{array}{l}\text { Mother and one } \\
\text { sister left }\end{array}$ & ? R. embolism & - & Left hemiplegia & Dysphasia : transient \\
\hline
\end{tabular}

a left-handed patient is due to involvement of the right hemisphere. Indeed, there are a number of well authenticated cases on record in which a lefthanded patient, with sinistral familial antecedents, has developed aphasia from a lesion in the left hemisphere (Tilney, 1936 ; Cole, 1936 ; Goodglass and Quadfasel, 1954). All that can be said with confidence is that if an ostensibly right-handed patient develops aphasia from a lesion in the right hemisphere, it is likely that inquiry will reveal some measure of ambilaterality in the patient and/or sinistrality in the family pedigree.

It has been reported by Penfield and his associates (Roberts, 1951 ; Penfield and Jasper, 1954) that no systematic difference can be ascertained in the kinds of aphasia produced by excision of different areas of the brain. From this it has been concluded that the classical types of aphasia consequent upon injury or disease of particular cortical areas are not duplicated by surgical excision of the areas in question. In view of this somewhat surprising finding, it is perhaps worth calling attention to the fact that the picture in the present case, more especially after remission of the expressive speech defect, was altogether comparable to that typically observed in cases of injury or disease involving the major temporal lobe. Indeed, the patient, in the later post-operative stages at least, may be said to have presented a classical "word-deafness" of moderate severity. The only atypical feature was perhaps the comparative lack of paraphasia and jargon, which do not, however, necessarily accompany receptive dysphasia. Although it may be argued that the patient's psychiatric disorder, which was unimproved by operation, indicates a cerebral dysfunction not limited to the temporal area, it is none the less of interest to note that a true receptive dysphasia, not present before operation, was in this case found to follow surgical excision of the (presumably major) temporal lobe.

The possibility still remains that speech was bilaterally represented in the case under discussion. This issue has been abundantly explored in the recent literature (Conrad, 1949; Subirana, 1952 ; Humphrey and Zangwill, 1952) and has been given systematic theoretical expression by Goodglass and Quadfasel (1954) in a valuable paper. Although it is a possibility which certainly cannot be ruled out, it must be borne in mind that many cases of unilateral lesion involving the language zones of one or other hemisphere have been reported in sinistrals without resulting dysphasia. Strictly 
unilateral representation of speech must therefore occur in some sinistrals at least. Although Goodglass and Quadfasel (1954) have allowed for this contingency in their theory of " cerebral ambilaterality", it must be admitted that no certain evidence of bilateral speech representation as yet exists. Until such evidence is to hand, it is perhaps wiser to conclude that language in the case under discussion was represented in the right hemisphere, and that this anomaly of dominance is to be linked with a weak constitutional sinistral strain.

\section{Summary}

A case is reported in which right temporal lobectomy was performed for the relief of temporal lobe epilepsy and associated psychiatric disturbances. Although preferentially right-handed, the patient developed severe post-operative dysphasia, especially marked and persistent in the receptive sphere. The significance of the findings in relation to handedness, familial sinistrality, and cerebral dominance is briefly considered.
We wish to express our gratitude to Dr. E. A. Carmichael and Mr. Wylie McKissock for their kind permission to study and communicate this case.

\section{REFERENCES}

Bramwell, B. (1899). Lancet, 11473.

Chesher, E. C. (1936). Bull. neurol. Inst. N.Y., 4, 556.

Claude, H., and Schaeffer, H. (1921). Rev. neurol., Paris, 28, 1170.

Cole, E. M. (1936). Arch. Neurol. Psychiat., Chicago, 35, 427.

Conrad, K. (1949). Nervenarzt., 20, 148.

Goodglass, H., and Quadfasel, F. A. (1954). Brain, 77, 521.

Humphrey, M. E., and Zangwill, O. L. (1952). Journal of Neurology, Neurosurgery and Psychiatry, 15, 184.

Kennedy, F. (1916). Amer. J. med. Sci., 152, 849.

Marinesco, G., Grigoresco, D., and Axente, S. (1938). Encéphale, $33(1), 27$.

Mendel, K. (1914). Neurol. Zbl., 33, 291.

Monrad-Krohn, G. H. (1947). Brain, 70, 405.

Penfield, W., and Jasper, H. H. (1954). Epilepsy and the Functional Anatomy of the Human Brain. Little, Brown and Co., Boston.

Pick, A., and Thiele, R. (1931). In Bethe's Handbuch der normalen und pathologischen Physiologie. ed. Bethe, A., Bergmann, G. von, Embden, G., and Ellinger, A., band 15, 2 hälfte, p. 1416. Springer, Berlin.

Roberts, L. (1951). Trans. Amer. neurol. Ass., 76, 43.

Rothschild, K. (1931). Amer. J. med. Sci., 182, 116.

Souques, A. (1910). Rev. neurol., Paris, 20, 547.

Stone, L. (1934). J. nerv. ment. Dis., 79, 1.

Subirana, A. (1952). Schweiz. Arch. Neurol. Psychiat., 69, 321.

Tilney, F. (1936). Arch. Neurol. Psychiat., Chicago, 36, 897.

Wilney, F. (1936). Arch. Neurol. Psychiat., Chicago, 36, 897. and Psychological Study. Commonwealth Fund, New York.

Whitty, C. W. M. (1954). Personal communication.

\section{THE MAY (1955) ISSUE}

The May (1955) issue contains the following papers :-

Studies in Traumatic Epilepsy, Part 3 : Visual Fits. W. Ritchie Russell and C. W. M. Whitty.

The Arterial Supply of the Spinal Cord and Its Significance. D. H. M. Woollam and J. W. Millen.

Encephalitis in Loa-Loa Filariasis. L. van Bogaert, A. Dubois, P. G. Janssens, J. Radermecker, G. Tverdy, and M. Wanson.

Observations on the Reaction Time to Cutaneous Thermal Stimuli. P. P. Lele and D. C. Sinclair.

Chronic Proliferative Osteitis of the Skull. J. E. M. Dutton and G. L. Alexander.

The Association of Dementia with Radiologically Demonstrated Cerebral Atrophy. R. H. Gosling.

Choroid Plexus Papilloma Causing Spontaneous Subarachnoid Haemorrhage. J. Ernsting.

The Use of Dehydroisoandrosterone in Psychiatric Practice. E. B. Strauss and W. A. H. Stevenson.

Ischaemic Sensory Loss in Patients with Spinal and Cerebral Lesions. R. W. Gilliatt.

Anxiety and an Autonomic Reaction to Pain. Malcolm Piercy, Alick Elithorn, R. T. C. Pratt, and Margaret Crosskey.

A number of copies are still available and may be obtained from the Publishing Manager, British Medical Association, Tavistock Square, W.C.1, price 12s. 6d. 